\title{
Corporate Social Responsibility for Mining Corporations: Balancing Profitability and Energy Sustainability by Mas Rahmah
}

Submission date: 02-Mar-2020 09:15AM (UTC+0800)

Submission ID: 1267164455

File name: Responsibility_for_Mining_Corporations_Energy_Sustainability.pdf (206.9K)

Word count: 5681

Character count: 32850 


\title{
27 \\ Corporate Social Responsibility for Mining Corporations: Balancing Profitability and Energy Sustainability
}

\author{
Mas Rahmah \\ Departement of Private Law, Faculty of Law \\ Universitas Airlangga \\ Surabaya-Indonesia \\ rahmah_arifin@yahoo.com
}

This paper aims at discussing the CSR for mining corporations to ensure energy sustainability. The paper argues that mining corporations, especially oil and gas companies sit directly at the heart of the energy production and half of all energy supplied to the world is provided by mining corporations, thus they have important role in ensuring energy sustainability. Contrarily, in nature they are the economic entities enhancing maximum profit at the expense of vulnerable energy, environmental degradation, mineral resources depletion that can be the perils of the energy sustainability. The paper asserts that the tre 41 of energy sustainability leads to emerging demand of Corporate Social Responsibility (CSR) for mining corporations to balance their profit orientation and responsibility to ensure the energy sustainability. This paper will contests the conflict between the nature of CSR and the nature of mining corporations as the economic agents aiming at profit maximization. The paper also evaluates whether ensuring energy sustainiblity by mining corporations can be considered as CSR. Then the paper analysis the dichotomy of imposing CSR for mining corporations based on voluntary or mandatory basis. Finally this paper highlights the need and the significance for mining corporations to balance their profitability against CSR in order to ensure energy sustainability.

Key words: CSR, energy sustainability, mining industries.

\section{INTRODUCTION}

The mining business operations affect directly to environment such as climate change, environmental degradation, water scarcity, declaining biodiversiy, natural resources depletion, energy unsustainability, etc. The impact associated with mining activity lead to the environmental awareness and resource conscious business practices, including energy sustainability. The vulnerable energy, the finite nature of non-renewable energy, natural and mineral resources depletion, and conversely the increase of global demand for energy more than $36 \%$ by $2035^{1}$ calls the need of global concern to overcome the treat of energy sustainability. The increased global concern to ensure energy sustainability is undeniable because of those challenges. Since those challenges caused by mining operations, the mining companies are pressing to improve the environmental performance of their operations and adopt envirome 4 al strategies as a commitment to the challenges. The mining sector is facing growing demand from governments, customers, communities and other key stakeholders to operate in a sustainable manner. Doing so has a growing influence on the mining industry's "social license" to operate.

Thus, there is growing demands placed upon the mining companies to balance their profit orientation and responsibility to ensure the energy sustainability by applying CSR to support green and sustainable investment. Mining companies are responsible for ensure the energy sustainibility since the energy production and half of all energy supplied to the world is provided by mining companies (particularly oil and gas enterprises). The mining companies also become the most CSR agents and the social responsible investors because their industry operations affect to mineral resources depletion, environmental degradation,water scarcity, land degradation 5 hd declaining biodiversiy. Mining companies need to active steps to examine their investment, capital expenditure and operational strategies to ensure 5 sustainable, environmentally friendly operations. In previous years, green and sustainable investments were not seen to provide significant returns on investment. However, with the rapidly changing regulatory and economic environment, return of investment are becoming increasingly attractive. When all the benefits of new technology and business practices of mining sector are accounted for, green and sustainable investments become a lot more attractive.

To investigate the responsibility of mining corporations to ensure energy sustainability, the anathomy of this paper has five structures. The first part will study the conflict between the nature of oil and gas industry as the economic entity aiming profit maximization, and the nature of CSR. The second part 
will evaluate whether ensuring energy sustainiblity by mining corporation can be considered as CSR. Then, the third part of paper will expose the dichotomy of imposing CSR based on voluntary and the mandatory basis. Finally, the fourth part will analysis the significance for mining corporations to balance their profitability against CSR in order to ensure energy sustainability.

\section{DISCUSSION}

\section{A. The Conflicting Nature of CSR and Mining Corporations \\ 1) The Nature of CSR}

Since the 1950s, the terminology of social responsibility has been used to denote a firm's responsibilities to society. ${ }^{2}$ CSR is a concept that is susceptible of myriad meanings. ${ }^{3}$ Sweeney and Coughlan argue that CSR has been suggested to be a broad, complex and evolving concept, which is ambiguous and subjective with unclear boundaries, ${ }^{4}$ J Jonker accords that CSR is a fuzzy concept. ${ }^{5}$ The fuzzy and ambiguous concept of CSR lead to the confusion about the definition and 16 eaning of CSR. According to M.B. E. Clarkson, the confusion and misunders 16 ding about the definition and meaning of CSR is a direct result of the inclusive and vague meaning of the word social. $^{6}$

Some argue that CSR has nature mainly on ethical and moral consideration when doing business, whereas, according t 39 rchie Carroll CSR has four basic nature i.e. economic, legal, ethical, and philanthropic. $^{7}$ In the pyramid of CSR developed by Archie Carroll, law forms the pyramid's base, while corporate philanthropy, ethical and moral dimensions, and the internalization of CSR strategy into firm operations (economic dimension) lie at the peak of the pyramid and evidence a more extensive commitment to

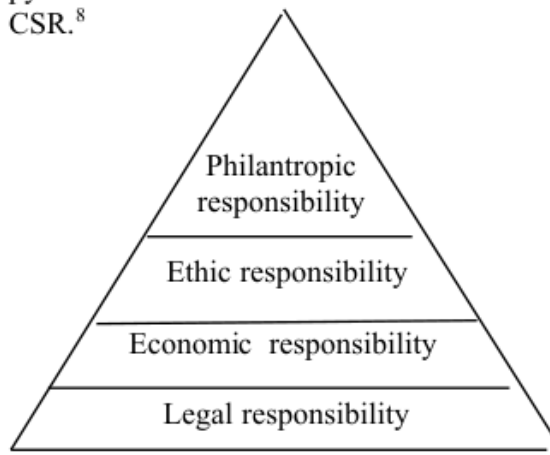

The concept of CSR encompasses the notion of corporate duties outside the business context. ${ }^{9}$ The expansive development of CSR concept suggests a shift away from view that business responsibilities are exclusively to shareholders, toward responsibility to a considerably wider range of social stakeholders and even wider community. ${ }^{10}$ The Euro $25 \mathrm{~h}$ Union (EU) has the same point of view by defining CSR as "the concept that an enterprise is accountable for its impact 9 all relevant stakeholders." " According to EU, CSR is the continuing commitment by business to behave fairly and responsibly and contribute to economic development while improving the quality of life of the work force and their families as w 40 as of the local community and society at large. ${ }^{12}$ Tom Fox, 14 ina Ward and Bruce Howard also give the similar definition of CSR: the commitment of business to contribute to sustainable economic development,working with employees, their families, the local community and society at large to improve their quality of life." 13

Based on OECD's perspective, CSR is expressed by the acti 37 taken by businesses to nurture and enhance the symbiotic relationship between businesses and the st8eties in which they operate. ${ }^{14}$ While Mc Williams and Siegel define CSR as action that appear to further some social good, beyond by interest of firm and that which is required by law. ${ }^{15} 12$

According to Catherine Olivier, et.all, CSR is closely linked with the principle of sustainability, which argues that corporations should make decisions based not only on financial factors, but also based on the longterm social and environmental consequences of their activities. ${ }^{16}$ Whereas, David Crowther and Guler Aras extend three basic principles which all together comprises CSR activities, that are, sustainability, accountability 23 transparency. ${ }^{17}$ Hemingway and Mclagan define CSR as the extent to which companies should promote human right, democracy, community improvement and sustainable development objective through world. ${ }^{18}$ European Commission also correlates the definition of CSR 20 environment by acknowledging that CSR is a concept whereby companies integrate social and environment concern in their business operations and interaction with their stakeholder in voluntary basis. ${ }^{19}$ Having the relativel 6 same perspective, the World Bank defines CSR as a term describing a company's obligations to be accountable to all of its stakeholders in all its operations and activities. ${ }^{20}$ Socially responsible companies consider the full scope of their impact on communities and the environment when making decisions, balancing the needs of stakeholders with their need to make a profit. $^{21}$

According to the CSR definitions, it can be concluded that there are various concepts and definitions are associated with the term of CSR, but 15re is no general agreement of CSR concepts ${ }^{22}$ and there is no single accepted definition of CSR. Most assume that CSR refers to an inherent compatibility with profitmaking and fulfilling the needs of society. ${ }^{23}$ The most definitions referred to CSR are an engagement in an 
activity without nece 32 ry focus on economic profit ${ }^{24}$ and balance of the needs of social stakeholders with their need to make a profit. ${ }^{25}$ Although CS is broad, fuzzy, complex, and evolving concept, susceptible of myriad meanings which is ambiguous and subjective with unclear boundaries, there are co21 mon definitions based on two basic dimensions: (1) how the company conducts its business ("good corporat 21 tizenship." and (2) the company.'s responsiveness to stakeholders, such as employees, local communities, and the environment. ${ }^{26}$ The first dimension emphazises that CSR encompasses efforts by the company to adhere to moral - ethical norms and to make a positive impact on society. Whereas the second dimension acknowledges that a company is not only accountable to its shareholders for the financial success of the firm, but that it also has an obligation to a wider range of constituencies. This dimension is often linked to the corporation's contribution to economic and environmental sustainability. ${ }^{27}$

\section{2) The nature of Mining corporations}

The nature of mining corporation are the economic enties that have main aim at profit margin maximization. There is econo 31 assumption that "business is business" and "to use the resources efficiently and engage in busil17. $\mathrm{s}$ activities designed to increase profits". Corporation was seen as an 'economic' institution, quite separate from 'social institutions' and in no wa 1 under the control of society, nor responsible to it. ${ }^{28}$ The very basis of a firm's responsibility is economic nature, so its primary obligation is to operate at a profit and to legitimately pu11 ie growth. ${ }^{29}$

According to Milton Friedman, the responsibility of corporations is to increase and maximize profits. ${ }^{30}$ Friedman declared that companies do not have social but only economic responsibility; instead of engaging in social philanthropic activities, the companies should focus on profit as economic gin has positive outcome on development as a whole. ${ }^{31}$ Society and welfare is not part of corporations' business. ${ }^{32}$ 1 1 is view represents neo-classical perspective called "predator capitalism", where the right of the more powerful prevails, and nothing but profit maximisation counts. ${ }^{33}$ Corporations operate of 1 owner rights, not human or social rights", reflecting their "raison d'être" which is maximization of net present value from the firm perspective, or of the respective returns from an owner perspective. ${ }^{34}$ Neoclassical economic observes that business responsibilities of companies are more exclusively to shareholders wealth. ${ }^{35}$ The responsibility of companies to shareholders wealth lies on the "shareholder primacy theory" tha 22 he goal of bussiness aims to maximise returns and all decisions made by company should be in interest of benefiting those who inve $7 \mathrm{~d}$ in the company. ${ }^{36}$ Moreover Friedman argued that in free economy : there is one and only one social responsibility of business - to use its resources and engage in activities designed to increase profits so long as it stays within the rules of the game, which is to say, engages in open and free competition without deception or fraud. ${ }^{37}$

According to Joel Lexchin, corporate activity in developing countries is motivated by business interest rather than efforts to provide social assistance. ${ }^{38}$ For most corporations, commercial interest and profit comes first, thus, ethical commitment and CSR does not 1 very deep ${ }^{39}$ and goes behind. Corporations fullfil its responsibility for society best if they engage in its core business activity as profitably as possible in lawful way. ${ }^{40}$

As corporations and economic entity, mining companies are responsible for maximizing profit and shareholder wealth. The corporations role in a global economy is to research, de $30 \mathrm{p}$ and produce energy for improving life quality and it is their duty to do so in a profitable way for increasing wealth and profit. Many corporations may protest that it is unreasonable to expect them to be overly altruistic and charitable and they a 2 for profit operations just like other businesses. ${ }^{41}$

The difficulty for mining companies is that, having accepted more responsibilities, they are then expected to do ever more - more than business priorities can justify. Firms have been loaded with increasing responsibilities in oil-producing countries because the often dysfunctional local governments 2 ave been unable to fulfil them. George Frynas details analysis of the mining industry's uneasy embrace of CSR) as a drama of sharp pressures on oil multinationals to take on more social functions, and the multinationals' mostly grudging and superficial responses. ${ }^{42}$ According to William Flaganan and G.Whiteman, usually the companies have two potential major 3 eaknesses when admitting CSR program i.e.; (a) lack effective processes for ensuring and 13 asuring the implementation of their CSR policies, (b) lack of meaningful participation by external stakeholders in policy development. ${ }^{43}$ In addition, there are potential risks related to the lack of meaningful progress of CSR programs: (a) damage to company reputation which could be more harmful; (b) damage to relationship with regulatory bodies which control the pricing; (c) restriction to the ability to access to market; (d) damage to staff morale. ${ }^{44}$

\section{B. Ensuring Energy Sustainability as CSR}

According to Virginia Harper Ho, one of CSR dimension is often linked to the corporations contribution to economic and environmental sustainability. ${ }^{45}$ Environmental sustainability includes the energy sustainability for addressing the unrenewable energy and energy vulnerability. Th29 European Commision has recognized that "creating an 
environment more conducive to enterprises voluntarily meets their social responsibility." 46

Ensuring energy sustainability is still a major problem in many developing counties. As the vital role of energy plays daily life, the lack of access should be ameliorated into a global policies. The energy sustainability debate has primarily focused on the accessibility, affordability and availability of energy to meet the present and future need of energy in sustainable way. 33

There is a growing demand of mining corporations to contribute to improved the sustainability of energy that can be considered as CSR. Initially, the most primary CSR of the mining corporation is to discover and develop renewable energy. According to this initial CSR, it has been assumed that the mining corporations become a le $38 \mathrm{ng}$ CSR performer and also increasingly recognized as a key player in the area of global energy since the primary role of mining corporations and their major CSR are to create and deliver new, innovative, technology in renewable energy, responsible in ensuring energy sustainability and improving the quality of life in society. The minning companies have been comfortable with the fact that they produce and develop renewable and sustainable energy as the evidence of their CSR. CSR looks compatible with the economical responsibility of mining corporations and become an integrated element of the strategies and operations for many mining industry. Although the corporations aim at maximizing the economical profit, the corporations have ethical and moral responsibility in society and act as well mannered citizens. The goal of the corporations should be transformed into comprehending aims by considering ethical and moral value more than mere economical profit focus to incorporate CSR. By engaging CSR, mining corporations likely realize their position as moral hybrids and not simply as profit making organization. ${ }^{47}$

The mining corporations often use charity mechanism by providing financial resources to specific state when aiming to incorporate CSR. However, the mere financial contribution and donations have been criticized because in fact these schemes do not solve the real problem behind the drawback of energy sustainability, only relieve some aspects for a short time. Donating money are beneficial, but it is an ad hoc arrangements that are not sufficient ${ }^{48}$ since the donation has not offered sustainable solution for the continued support of global need to energy sustainability. Therefore, this paper recommends that the charity philanthropic donations of drugs and financial resources should be accompanied by other important mechanisms such evaluate their investments and business activities by investing the energy access, energy security, energy efficiency, and renewable energy.

Moreover, corporations have the duty to cover the environmental implications of the company's operations, products and facilities; eliminate waste and emissions; maximize the efficiency and productivity of its resources; and minimize practices that might adversely affect the enjoyment of the country's resources by future generations. The companies in a wide range of mining 19 ectors and geographic regions should contribute concrete value and compef19e advantages from taking environmental initiatives, such as pollution prevention, environmentally oriented design, supply-chain management, industrial ecology, energy efficiency and sustainability.

10 The eco-efficiency is needed for mining sector producing more energy while using fewer resources and producin 10 ess waste and pollution because mining industry requires intensive use of natural raw materials and energy. It also results in emissions to the atmosphere, the most significant is carbon dioxide (CO2). Mining corporations need to actively involved in a range of environmental programs and have integrated all their environmental programs into mainstream operations to provide energy sustainability by switching to greener energy suppliers.

\section{Imposing CSR For Mining Corporations : the Dichotomy}

Since mining operations affect directly to environment, the mining companies are pressing to improve the environmef 4 al performance and adopt enviromental strategies. The mining sector is facing growing demand from governments, customers, communities and other key stakeholders to operate in a sustainable manner by applying CSR. The CSR initiatives is imposed on mining corporations in order to ensure energy sustainability.

However some argue that engagement of CSR should be voluntary business case rather than normative imposition. According to N. Craig Smith CSR can be categorized into business and normative case, ${ }^{49}$ while Klaus Michael Leisinger, et all prescribes thee levels of CSR : the " must", the "ought to" and the "can" dimension..$^{50}$ The 'must' dimension is non-negotiable essentials incumbent on the respective industry by social consensus; the 'ought to' dimension is good corporate responsibility standards particularly relevant in sensitive business areas, or countries where the quality of the law is insufficient or inadequately enforced; the 'can' dimension is voluntary assumption of additional responsibility according to capacity. ${ }^{51}$

In common 3 oncept, debates of CSR engagement are often framed as a simple dichotomy: voluntary compliance by companies versus regulatory enforcements by governments. Some argue that CSR is a voluntary engagement rather than mandatory. According to Virginia Harper Ho, CSR is typically understood as voluntary actions companies take beyond what is required by law. ${ }^{52}$ This concept implies that CSR operates exclusively beyond regulation and at the 
113 iative of private, rather than public actors. ${ }^{53}$ According to European Commission, CSR is a concept whereby companies integrate social and environmental concerns in their business operations and in their interaction wit 11 heir stakeholders on a voluntary basis. ${ }^{54}$ CSR should nevertheless not be seen as a substitute to regulation or legislation concerning social rights or environmental standards, including the development of new appropriate legislation. ${ }^{55}$ As the voluntary nature of CSR, the operation of CSR are based on soft law rather than hard enforceable legal mandates.

The counter arguments suggest that CSR is an action required by law. ${ }^{56}$ They assume that the voluntary CSR initiatives lead to meaningless CSR policies and are insufficient ${ }^{57}$ to address the need 3r energy sustainability. Therefore, it is necessity of active, multifaceted, and innovative government participation ${ }^{58}$ in pressuring mining companies to engage meaningfully in CSR-related actio 36 to ensure energy sustainability. Strong role of governments and international organizations will likely then pres 3 e companies to perform CSR better. Government action can ensure effective delivery of CSR commitments, over and above voluntary CSR actions undertaken by mining companies. As mandatory, the corporation must comply to the regulation, policymaking, standard setting, and other forms of governmental facilitation of CS28 and adoption of responsible business practices. Being socially responsible means not only fullfill legal expectation but also going beyond compliance. Legal compliance is 26 lely recognized as a foundational element of CSR and respect for applicable legislation, and for collective agreements between social partners, is a prerequisite for CSR. $^{59}$

\section{The Need and Significance of Balancing Profitability and CSR 1) Benefit of CSR}

Mining corporations need to balance their goal and business operations against CSR obligation since CSR allows the mining corporations to gain benefit of CSR initiatives. The debates over CSR benefit and its impacts can be classified into three correlations; neutral, negative and positive correla 35 . $^{60}$ While the neutral correlation perspective suggests that there is no relation between CSR and financial performance, the negative correlation perspective argues that corporations are at a competitive advantage by spending resources on CSR. ${ }^{61}$ The nature of social responsibility conflicts to the nature of corporations because considering CSR often results in less short term profit for the corporation. The opponent of CSR claims that CSR has correlation with high costs and affects the economic profit negatively. ${ }^{62}$

Conversely, the perspective of positive correlation suggests that there is a competitive advantage and long term success by engaging in CSR initiatives. ${ }^{63}$ Engaging in active CSR may contribute positive image of the corporations, indicating awareness, corporation stability and social care. Ignoring CSR may put the corporations under the down-mark rankings and rating due to the lack of social engagement. According to Marquez and Fombrun, by engaging CSR companies have been striving to achieve a favorable ratings on their performance which can result in awards, applause, sales and reputation. ${ }^{64}$ Combining satisfactory profit with CSR aware decisions often results in less short term profit, but contributes to greater good and strong reputation in the future, enhance goodwill towards interested parties. Corporation with strong CSR will often be more successful in generating economic value added, for reason rooted in business strategy. ${ }^{65}$ CSR is not a high cost affecting economical performance negatively, but it should be seen as a business competitiveness strategy. There is a linkage between CSR and corporate reputation and goodwill influencing the consumer satisfaction and attracting investor, shareholders or other interested parties. Therefore, CSR is increasingly important to international business. Recently, CSR becomes fashionable and it is used by corporations to attract clients, investor, shareowners etc. Corporations use CSR as a marketing approach to enhance and maximize the brand image or profiles of corporation. ${ }^{66}$

\section{2) Role of Government}

Recently, CSR cannot be defined simplistically in terms of distinctions between voluntary tools or soft law and hard law. Indeed, legal compliance for CSR is widely recognized as a basic element of CSR. Legal obligations and CSR commitments that go beyond regulation can be enforced using a range of tools that span the suppose 34 divide between voluntary and mandatory rules. CSR and the law are therefore intertwined and mutually influencing. ${ }^{67}$ The voluntary CSR commitments can influence the content of future CSR regulation. While regulation, policymaking, standard setting, and other forms of governmental facilitation of CSR can influence firms voluntary adoption of responsible business practices beyond enhanced compliance with legal rules.

From the mandatory perspective, a government role in CSR is carried out through its core legislative and enforcement function, and the most aspect of CSR, such as environmental protection is already the subject of independent legal obligations. ${ }^{68}$ The boundary between CSR and the law blurs when governments involves in setting CSR policies and integrate those policies into their traditional legislative and regulatory functions. ${ }^{69}$ Government have experimented with a range of regulatory tools to address the limit of economic and social interactions, from traditional command-and control, penalty-based regulation toward a mix of strategies including reliance on cooperative 
tools that emphasize voluntary and quasi-voluntary strategies, rather than the threat of penalties, to influence corporate and individual behavior. ${ }^{70}$ CSR policy tools developed by goverment replicate or reinforce the cooperative-or compliance-oriented enforcement strategies. CSR policy tools (including regulatory and cooperative ) include penalty waivers for self-disclosure of violations, educational programs, and financial incentives for firms who implement voluntary internal compliance systems. ${ }^{71}$

Therefore, the goverment role has evolved from traditional role of mandating that contemplates as legislator and regulator to faciliting, partnering and endorsing CSR. By endorsing CSR, governments raise awareness by providing information dissemination, training, and educational program, building CSR into public procurement and other contracting 24 uirements. ${ }^{72}$ At facilitating role, goverment provides standard setting, voluntary guideline, certification systems, auditing and monitoring, establishing financial and reputational incentives for firms. Government also facilitate CSR by enacting regulation that support civil organizations and implementing multilateral conventions and guidelines. The government tools to facilitate CSR practices also consist of government subsidized services to aid firms in CSR reporting, targeted CSR trainings, and other forms of capacity building. ${ }^{73}$ While at partnering role, the tools include the public private partnership between goverment and companies on specific projects, government participation in efforts of international organizations to promote CSR, goverment mediated CSR dialogue involving corporations and other stakeholders. ${ }^{74}$ The partnership between governments and corporation can be bidirectional where both contribute to evolving practices and policies. ${ }^{75}$ Partnerships around CSR issues can become a three-way collaboration between governments, the business community, and civil society organizations, in which governments serve as initiators, moderators, or facilitators. ${ }^{76}$ Governments may also directly have joint working group with civil society organizations and firms in designing, implementing, and monitoring CSR and developing CSR policy. ${ }^{77}$ At mandating role, goverment requires CSR adoption through legislation and regulatory enforcement that include mandatory sustainability reporting and standards for corporate codes of conduct that may reach beyond legal compliance. ${ }^{78}$ The European Comission has recognized that traditional top-down regulation plays an important complementary role in meeting social responsibility. ${ }^{79}$ Positive law and related regulations serve as a foundation on which CSR initiatives may build,$^{80}$ and law is the only one of many source of norms that ground economic and social interacttions and its limits. ${ }^{81}$

\section{CONCLUSION}

Although there is conflicting nature of mining companies as the economic entity and the nature of CSR, evolutionary, CSR is increasingly important and becomes fashionable used by mining corporations to attract clients, investor, shareholders, etc. and for marketing and business competitive strategy to enhance and maximize the brand image or corporation profile. To ensure energy sustainability, it is necessary to balance the profitability of mining corporations and environmental concern by imposing CSR and enhancing the role of government to regulating, faciliting, partnering and endorsing CSR.

\section{References :}

1. World Energy Outlook, "Power sector cumulative investment by type and region in the New Policies Scenario", 2013-2035," OECD/IEA, 2013.

2. Archie Carroll, "Corporate Social Responsibility", Business and Society, Vol. 38(3), 1999, p. 268-295.

3. Communication from the Commission to the European Parliament, the Council, the European Economic and Social Committee, and the Committee of the Regions: A Renewed EU Strategy for 201114 for Corporate Social Responsibility, para 3.1, COM (2011) 681 final (Oct. 25, 2011) [hereinafter EC 2011 CSR Strategy], available at http://ec.europa.eu/enterprise/policies/sustainablebusiness/corporatesocialresponsibility/index_en.html.

4. L.Sweeney, J. Coughan, "Do Different Industries Report Corporate Social Responsibility Differently? : An Investigation Through the Lens of Stakeholder Theory", Journal of Marketing Communication, Vol 14 (2), 2008, p. 113.

5. J Jonker, "In Search of Society: Redefining Corporate Social Responsibility, Organisational Theory and Business Strategies", in J. A. Batten and T. A. Fetherston (eds.), Social Responsibility: Corporate Governance Issues, Oxford, Elsevier Science, 2003, p. 423-39.

6. M.B. E. Clarkson, "A Stakeholder Framework for Analyzing and Evaluating Corporate Social Performance", Academy of Management Review, Vol. 20, No. 1, 1995.

7. Archi Carroll, above note 2.

8. Archie B. Carroll, "The Pyramid of Corporate Social Responsibility: Towards the Moral Management of Organizational Stakeholders", BUS. HORIZONS, July-Aug 1991, p. 40-43.

9. Lisa Forman, Jillian C. Kohler, 'Introduction: Access to Medicines as a Human Right - What Does it Mean for Pharmaceutical Industry Responsibilities?", in Lisa Forman and Jillian Clare Kohler, (eds)., Access to Medicines as a Human Right: Implications for 
Pharmaceutical Industry Responsibility, University of Toronto Press, 2010, p.5.

10. Paula Darvas, "Grounding the Social Responsibility of Companies in the Language of Human Rights: a Survey of the Issues," Australian Journal of Corporate Law, Vol. 20, 2007, p. 139.

11. EU, "Promoting a European Framework for Corporate Social Responsibility", EU Green Paper (18/07/2001), 2001. http://europa.eu.int/comm/employment_social/socdial/csr/greenpaper_en.pdf

12. Ibid.

13. Tom Fox, et all, "Public Sector Roles in Strengthening Corporate Social Responsibility: a Baseline Study", 2002, p.1.

14. Peggy Chiu, Looking Beyond Profit : Small Shareholders and the Values Imperative, Gower Publishing Limited, USA, 2009, p.31

15. A McWilliam, "Corpotrate Social Responsibility : A Theory of the Firm Perspective", Academy of Management Review, Vol 26, 2001, p.207

16. Catherine Olivier, et.all, Current Pharmacogenomics and Personalized Medicine, Vol. 6, No. 2, 2008, p. 114.

17. David Crowther, Guler Aras, Corporate Social Responsibility, Ventus Publishing, 2008, p.14

18. C.A Hemingway, P.W. Mclagan, "Manager Personal Values as Driven of Corporate Social Responsibility, Journal of Bussiness Ethics, Vol. 50, 2004, p. 33.

19. David Crowther, Guler Aras, above note 17, p.11

20. Deborah Doane, "Beyond Corporate Social Responsibility: Minnows, Mammoths and Markets," Futures, Vol. 37, 2005, p. 217.

21. Ibid.

22. Michael Hopkins, The Planetary Bargain : Corporate Social Responsibility Matters, Earthscan Publications Ltd, 2003, p.9.

23. Deborah Doane, above note 20, p. 216.

24. Karin Czubala, "Is Access to Medicines A Corporate Social Responsibility", Tesis, 2008., p. 27.

25. Deborah Doane, above note 20, p. 217.

26. Virginia Harper Ho, "Beyond Regulation: A Comparative Look at State-Centric Corporate Social Responsibility and the Law in China", Vanderbilt Journal of Transnational Law, Vol. 46, 2013, p, 382.

27. Ibid, p. 383.

28. Michael Hopkins, above note 22, p.13.

29. T.S. Pinkston, Carroll AB, "A Retrospective Examination of CSR Orientations: Have They Changed?", Journal of Business Ethics, Vol. 15, 1996, p.205

30. Viktor J. Vanberg, "Corporate Social Responsibility in a Market Economy: The Perspective of Constitutional Economics," in Lorenzo Sacconi, et all (ed), Corporate Social Responsibility and Corporate Governance, The Contribution of Economic Theory and Related Disciplines, Palgrave Macmillan, 2011, p. 131.

31. Karin Czubala, above note 24, h. 26

32. Mag Christina Keinert, Corporate Social Responsibility as an International Strategy, PhysicaVerlag Heidelberg, 2008, p. 59

33. Ibid

34. Ibid

35. Milton Friedman, New York Magazine, 13 September 1970

36. Sabina Medarevic, "Environmental Corporate Social Responsibility and the Carbon Economy: a Case For CSR, the Triple Bottom Line snd Obliquity", Bond Corporate Governance eJournal, 2012, p. 1.

37. Viktor J. Vanberg, above note 30, p. 131

38. Lisa Forman and Jillian Clare Kohler, above note 9, p. 12 .

39. Matthew Lee, Jillian Kohler, "Benchmarking and Transparency: Incentives for the Pharmaceutical Industry's Corporate Social Responsibility", Journal of Business Ethics, Vol. 95, 2010, p. 651.

40. Mag Christina Keinert, above note 32, p. 59.

41. Sarah Joseph. "Pharmaceutical Corporations and Access to Drugs: The "Fourth Wave" of Corporate Human Rights Scrutiny", Human Rights. Quartley, Vol 25, 2003, p. 436.

42. Jedrzej George Frynas, Beyond corporate social responsibility: oil multinationals and social challenges, Cambridge University Press, Cambridge, 2009, p. 39.

43. William Flanagan, Gail Whiteman, "Aids is Not a Business : A Study in Global Corporate Responsibility-Securing Access to Low-Cost HIV Medications", Journal of Business Ethics, Vol. 73, 2007, p. 66.

44. Ibid

45. Virginia Harper Ho, above note 26, h.382.

46. Sean D. Murphy, "Taking Multinational Corporate Codes of Conduct to the Next Level", Colum. J. Transnat. 'L L., Vol. 43, 2005, p. 389.

47. Lisa Forman, Jillian Clare Kohler, above note 9, p. 11

48. Phillippe Autier et al, "Drug Donations in Postemergency Situations", Discussion Paper Series, World Bank Health, Nutrition \& Population Family, 2002, available http://siteresources.worldbank.org/HEALTHNUTRIT IONANDPOPULATION/Resources/2816271095698 140167/Nassery-DrugDonation-whole.pdf.

49. N. Craig Smith, "Corporate Social Responsibility: Not Whether, But How?", Working Paper No. 03701, London Business School, April 2003, p.3.

50. Klaus M. Leisinger, "Corporate Responsibilities for Access to Medicines', Novartis Foundation for Sustainable Development, 2008, p. 5.

51. Ibid, p. 9.

52. Virginia Harper Ho, above note 26, p.383. 
53. Ibid.

54. European Commission, "Green Paper : Promoting a European framework for Corporate Social Responsibility", 2001, para 20.

55. Ibid, para 22.

56. Mc William, P.M. Wright, D.S. Siegel, "Guest Editors: Introduction Corporate Social Responsibility", Journal of Management Studies, Vol 43 (1), 2006, p.207.

57. William Flanagan, Gail Whiteman, "Aids Is Not a Business : A Study in Global Corporate Responsibility-Securing Access to Low-Cost HIV Medications", Journal of Business Ethics, Vol. 73, 2007,p. 66.

58. Ibid, p. 73

59. Virginia Harper Ho, above note 26, p.383.

60. European Commission, "Green Paper : Promoting a European framework for Corporate Social Responsibility", 2001, para 20.

61. Jennifer Zerk, Multinationals and Corporate Social Responsibility: Limitations and Opportunities In International Law , Cambridge University Press, 2006, p. 35.

62. Ibid

63. Virginia Harper Ho, above note 26, p.385.

64. Ibid

65. Tom Fox, above note 13, p. 6-8.

66. Ibid.

67. Ibid, p. 5

68. Josep M. Lozano, et al, Governments And Corporate Social Responsibility: Public Policies Beyond Regulation And Voluntary Compliance, Journal of Business Ethics, vol 74, 2007, p. 37.

69. Ibid, p. 35

70. Tom Fox, above note 13 , p. 22.

71. Laura Albareda et al., "The Changing Role of Governments in Corporate Social Responsibility: Drivers and Responses, Bus. Ethics: Eur. Rev., Vol 17, 2008, p. 350

72. Sean D. Murphy, above note 46, p. 389.

73. Christine Parker, The Open Corporation: Effective Self-Regulation And Democracy, Cambridge University Press, Cambridge, 2002, P. 245.-91, cited from Virginia Harper Ho, Op.Cit, p. 385.

74. Ibid.

75. Mc William, P.M. Wright, D.S. Siegel, "Guest Editors: Introduction Corporate Social Responsibility", Journal of Management Studies, Vol 43 (1), 2006, p. 11-12.

76. Matthew Lee, Jillian Kohler, above note 39, p. 649

77. Karin Czubala, above note 24, p. 33

78. Matthew Lee, Jillian Kohler, above note 76.

79. A. Marquez, C.J. Fombrun, "Measuring Corporate Social Responsibility, Corporate Reputaion Review, Vol 7 (4), 2005.

80. Karin Czubala, above note 24, p. 32
81. Ilias Bantekas, "Corporate Social Responsibility in International Law", Boston University International Law Jurnal, Fall 2004, p. 340. 


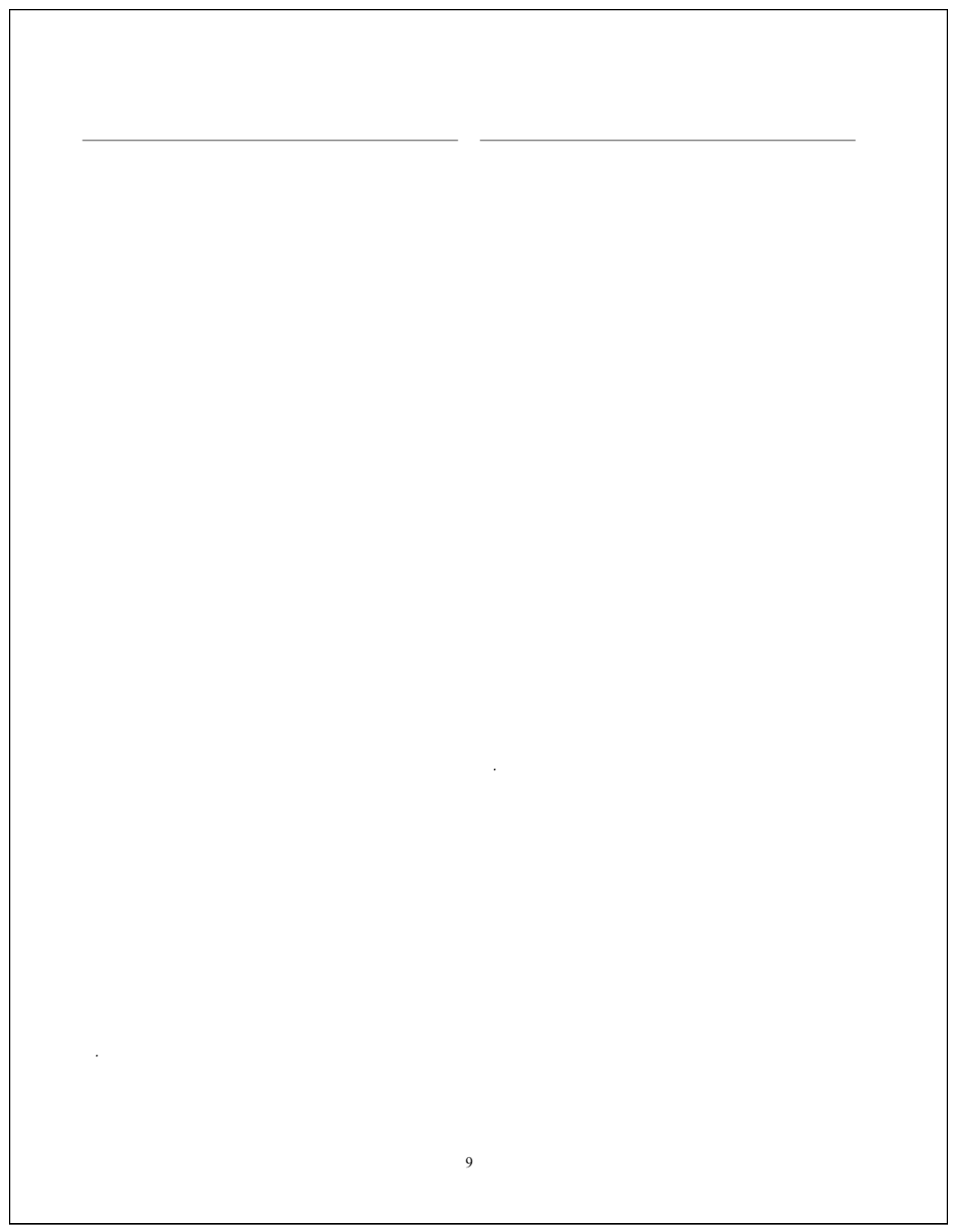


Corporate Social Responsibility for Mining Corporations: Balancing Profitability and Energy Sustainability

ORIGINALITY REPORT

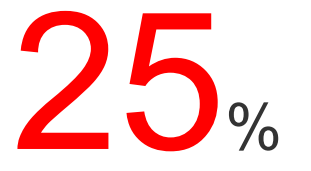

SIMILARITY INDEX
$19 \%$

INTERNET SOURCES
$19 \%$

PUBLICATIONS
$0 \%$

STUDENT PAPERS

PRIMARY SOURCES

1

"Corporate Social Responsibility as an

International Strategy", Springer Science and

Business Media LLC, 2008

Publication

2 www.wenar.info Internet Source

William Flanagan, Gail Whiteman. "'AIDS is Not

a Business": A Study in Global Corporate Responsibility - Securing Access to Low-cost HIV Medications", Journal of Business Ethics, 2006

Publication

4 ey.mobi Internet Source

Mohammad Safari Kahreh, Seyyed Mehdi Mirmehdi, Asghar Eram. "Investigating the critical success factors of corporate social 
responsibility implementation: evidence from the Iranian banking sector", Corporate Governance:

The international journal of business in society, 2013

Publication

$7 \quad$ scholarbank.nus.edu.sg

Internet Source

8 www.amfiteatrueconomic.ro

Internet Source

$9 \quad$ www.abi.org.uk

Internet Source

10 www.cimentstlaurent.com

Internet Source

11 ngeblog1.blogspot.com

Internet Source

12 www.bentham.org

Internet Source

13 www.reedsmith.com

Internet Source

14 www.cuhkemba.net

Internet Source

$1 \%$

15 www.wild-fire.info

Internet Source

Otuo Serebour Agyemang, Abraham Ansong, 
Millicent Kyeraa. "Let's talk about firm

responsibility: the perception of individual

Ghanaian shareholders on corporate social

responsibility", Social Responsibility Journal,

2016

Publication

17 Michael Hopkins. "Chapter 1 Why Socially

Responsible Enterprises?", Springer Science and Business Media LLC, 1999

Publication

18

Werner Hediger. "Welfare and capital-theoretic foundations of corporate social responsibility and corporate sustainability", The Journal of

Socio-Economics, 2010

Publication

19 www.afedonline.org

Internet Source

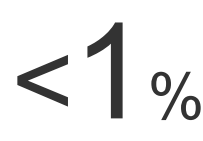

20 www.shs-conferences.org

Internet Source

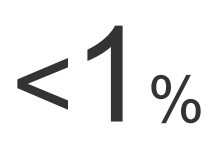

21 "Globalisation of Corporate Social Responsibility

and its Impact on Corporate Governance",

Springer Science and Business Media LLC,

2018

Publication 


\section{4 sites.duke.edu}

25 jcsr.springeropen.com

26 www.sustainvalue.eu

27 www.scilit.net

28 res.mdpi.com

29 www.ibimapublishing.com

30 www.ghd-net.org Internet Source

31 www.bestenvironmentpro.com Internet Source

Rakhi Rashmi. "chapter 12 Corporate Social

Responsibility of Pharmaceutical Industry

Towards Access to Medicine: A Case Study of

GlaxoSmithKline", IGI Global, 2017 
34 digitalcommons.law.umaryland.edu Internet Source

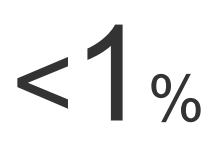

35 www.kantakji.com

Internet Source

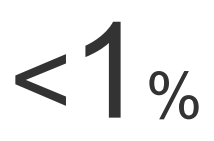

36 www.etnor.org

Internet Source

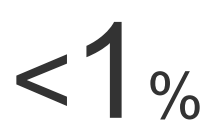

37 Mariela Casanova Claros. "Corporate social

responsibility: a perspective from Peru",

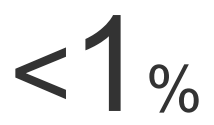

International Journal of Liability and Scientific

Enquiry, 2011

Publication

38 www.iea.org

Internet Source

39 researchonline.jcu.edu.au

Internet Source

40 Nakib Muhammad Nasrullah, Mia Mahmudur

Rahim. "CSR in Private Enterprises in

Developing Countries", Springer Science and

Business Media LLC, 2014

Publication

41

Mark Anthony Camilleri. "Corporate

Sustainability, Social Responsibility and

Environmental Management", Springer Science and Business Media LLC, 2017

Publication 
Exclude quotes

Off

Exclude matches

Off

Exclude bibliography

On 